Ptak M. (2014). Environmental charges levied on power plants. Copernican Journal of Finance \& Accounting, 3(2), 127-136. http://dx.doi.org/10.12775/CJFA.2014.022

\author{
Michat Ptak* \\ Wrocław University of Economics
}

\title{
ENVIRONMENTAL CHARGES LEVIED ON POWER PLANTS
}

Keywords: environmental protection, environmental charges, power generating plants.

\section{J E L Classification: H23.}

Abstract: The aim of the article is to analyze the financial burden on energy sector in Poland resulting from charges on the use of the environment. The estimation of the amount of charges paid by the power plants is based on data on emissions of basic pollutants from this sector.

The starting point for the analysis is the brief evaluation of the impact of Polish energy sector on the environment. The impact is quite significant due the fact that electricity generation is mainly based on solid fuels, such as hard coal and lignite. The environmental consequences of such energy production method are large emissions of gases and dust. During the electricity production process large amounts of waste are also generated (e.g. slag, ash). In addition, the energy sector extracts the water and discharges wastewater into the water or soil.

The study shows that power plants pay all four kinds of charges for the use of the environment, such as air pollution charges, water abstraction charges, landfill charges and water pollution charges. Particularly important are charges for gases that are emitted into the atmosphere. The charges paid by the energy sector account for a significant proportion of revenues from charges on the use of the environment.

Date of submission: April 22, 2014; date of acceptance: August 14, 2014.

* Contact information: michal.ptak@ue.wroc.pl, Faculty of Economy, Management and Tourism in Jelenia Góra, Wrocław University of Economics, Nowowiejska 3, 58-500 Jelenia Góra, Poland, phone: 757538221. 


\section{OPEATY PONOSZONE PRZEZ ENERGETYKĘ W ZWIĄZKU Z KORZYSTANIEM ZE ŚRODOWISKA}

Słowa kluczowe: ochrona środowiska, opłaty ekologiczne, energetyka zawodowa.

Klasyfikacja J E L: H23.

Abstrakt: Celem artykułu jest analiza obciążeń sektora energetycznego w Polsce z tytułu opłat za korzystanie ze środowiska. Szacunki wysokości opłat wnoszonych przez energetykę oparte są na danych o emisjach podstawowych zanieczyszczeń z tego sektora.

Punktem wyjścia dla tych rozważań jest krótka ocena wpływu polskiej energetyki na środowisko. Wpływ ten jest dość istotny w związku z tym, że w Polsce energia elektryczna wytwarzana jest głównie w oparciu o paliwa stałe, takie jak węgiel kamienny i brunatny. Związane są z tym określone skutki ekologiczne, przede wszystkim emisja gazów oraz pyłów. W procesach produkcji energii elektrycznej powstają również znaczne ilości odpadów, takich jak żużel czy popiół. Poza tym sektor energetyczny pobiera wodę i wprowadza ścieki do wód czy do ziemi.

Z przeprowadzonych badań wynika, że sektor energetyki zawodowej ponosi wszystkie rodzaje opłat za korzystania ze środowiska - za wprowadzanie gazów i pyłów do powietrza, pobór wód, wprowadzanie ścieków do wód lub do ziemi oraz składowanie odpadów. Szczególnie duże znaczenie mają opłaty za emisję gazów do powietrza, gdyż opłaty wnoszone przez sektor energetyki stanowią znaczny odsetek całkowitych wpływów z tytułu opłat za korzystanie ze środowiska.

\section{IIITRODUCTION}

Conventional power plants generate significant external costs. These costs are mainly associated with the resources depletion and emissions of combustion products into the atmosphere. Other nuisances include wastes and wastewater discharges into the environment.

One can assume that conventional power plants - as agent affecting the environment on a large scale - are subject to relatively high environmental levies. These levies include inter alia charges for the use of the environment that is air pollution charges, water abstraction charges, landfill charges and water pollution charges (Gad, Pawlak, Różowicz 2013, 42). In Poland these charges have a long tradition. For example charges on $\mathrm{NO}_{\mathrm{x}}$ emissions were introduced in 1980.

The purpose of the paper is the analysis of the financial burden on energy sector in Poland resulting from charges on the use of the environment. Due to the limited length of the article the paper is mainly focused on the air pollution charges. 


\section{THE RESEARCH METHODOLOGY AND THE COURSE OF THE RESEARCH PROCESS}

The paper is mainly based on review of literature and on statistical data provided by Central Statistical Office. The paper also reviews available reports of energy companies or individual power stations.

The available data do not contain detailed information on the structure of revenue from charges on the use of the environment. The estimation of the amount of environmental charges paid by the power plants in Poland is based on statistical data on emissions of pollutants into the air and on rates of emission charges which are given in environmental regulation. It should be noted that some estimates of environmental charges paid by individual power station or the structure of the revenues from the charges can be found in the literature (Gad et al., 2013; Poskrobko 1999).

The paper also contains a brief analysis of rates of emission taxes and charges applied in other European countries and a case study approach based on environmental statements published by a selected power generation company.

\section{THE OUTCOME OF THE RESEARCH}

Poland belongs to the small group of countries that rely mainly on solid fuels (coal and lignite) as their electricity and heat source. The dependence on these fossil fuels is obviously a consequence of availability of coal, the absence of significant amounts of other energy sources and the existing infrastructure manufacturing (Lorenz 2005). During the combustion of solid fossil fuels large emissions of gases and particles are produced. Furthermore, power plants generate waste, use water and discharge wastewater. In Poland these activities are subject to environmental charges (table 1). The design of "green" charges is fairly complex. For example, air emission charges are levied on 67 substances, whereas in Western European countries environmental taxes are rather product taxes levied on fuels (for example according to the sulphur content). There are only some pollutants which are directly or indirectly subject to environmental taxes (mainly $\mathrm{CO}_{2}$ and $\mathrm{SO}_{2}$ ). 
Table 1. The environmental impact of power plants subject to charges on the use of the environment

\begin{tabular}{|l|l|}
\hline \hline Charges for the use of the environment & \multicolumn{1}{|c|}{ Use of the environment subject to the charges } \\
\hline \hline Air pollution charges & $\begin{array}{l}\text { The combustion of coal in power plants is the source of emissions of } \\
\text { pollutants, including nitrogen oxides, sulphur dioxide, carbon oxide or } \\
\text { carbon dioxide. Power plants are also a source of emissions of heavy } \\
\text { metals (such as arsenic, cadmium, chromium, lead, mercury, nickel and } \\
\text { zinc) which also are subject to air pollution charges. }\end{array}$ \\
\hline Water abstraction charges & $\begin{array}{l}\text { Power stations abstract water primarily for cooling the power-produ- } \\
\text { cing equipment. }\end{array}$ \\
\hline Water pollution charges & $\begin{array}{l}\text { Power stations discharge wastewater (including water used as a co- } \\
\text { olant) into the environment. }\end{array}$ \\
\hline $\begin{array}{l}\text { Landfill charges (on waste disposed in } \\
\text { landfills) }\end{array}$ & $\begin{array}{l}\text { Wastes from power plants include mainly combustion waste products } \\
\text { such as dust and slag (so called furnace waste) and waste from desul- } \\
\text { phurization. Waste disposed in landfills can be reduced by using waste } \\
\text { in some processes, for example in construction, mines or road con- } \\
\text { struction. Wastes can be also given to licensed companies. }\end{array}$ \\
\hline \hline
\end{tabular}

S o u r c e : Deklaracja środowiskowa za rok 2011 2012, 14; 16-17; Deklaracja środowiskowa 2012, 21-22; Deklaracja środowiskowa wg Rozporządzenia EMAS 2011; Gad et al., 2013; Lorenz 2005; Pyssa 2005, 83-84.

One of the important environmental problem associated with combustion of fossil fuels are emissions of sulphur dioxide and nitrogen oxides. For many years public power plants and thermal power plants have been the main source of $\mathrm{SO}_{2}$ and $\mathrm{NO}_{\mathrm{x}}$ emissions in Poland. According to the Eurostat data, in 2011 emissions of sulphur oxides and nitrogen oxides from the energy production and distribution sector in Poland were among the highest in Europe. Despite this, the rates of emission charges in Poland are still very low in comparison to taxes levied in Northern European countries (table 2) ${ }^{1}$.

${ }^{1}$ However it should be noted that taxes paid in Sweden are refunded to the taxpayers. For example, the tax on sulphur (levied not directly on emissions but on coal, coke and peat) is refunded when measures are taken to reduce $\mathrm{SO}_{2}$ emissions. The revenue from NOx charges is refunded to the regulated plants on the basis of their energy production. The "winners" of the system (that is firms which receive more from the refund than what they paid in taxes) include combined heat and power generation sector. Skatter i Sverige 2011, 143; The Swedish tax. 
Table 2. Rates of charges and taxes on $\mathrm{NO}_{\mathrm{x}}$ and $\mathrm{SO}_{2}$ in chosen European countries in 2014 (in PLN per kg)

\begin{tabular}{|l|c|c|}
\hline \multicolumn{1}{|c|}{ Country } & NOx & SO2 \\
\hline \hline Czech Republic & 0,22 & 0,18 \\
\hline Denmark & - & 6,41 \\
\hline Estonia & 0,47 & 0,47 \\
\hline Norway & 9,02 & - \\
\hline Poland & 0,53 & 0,53 \\
\hline Sweden & 24,50 & 7,35 \\
\hline \hline
\end{tabular}

S o u r c e : Elektrimajanduse regulatiivne keskkond; Database on instruments; Emisní poplatky 2012; Tax.dk; Excise duty on emissions of NOx. 2014; Obwieszczenie Ministra Środowiska 2013.

As mentioned, detailed information on the structure of revenue from environmental charges is not available. However, one can estimate the revenues from emission charges levied on energy sector taking data on emissions as a basis for calculation. According to the Table 3, the estimated charges on $\mathrm{CO}_{2}$, $\mathrm{CO}, \mathrm{NO}_{\mathrm{x}}$ and $\mathrm{SO}_{2}$ paid by public power plants and thermal power plants in 2011 was 326 million PLN². Similar calculations indicate that charges on heavy metals paid by public power plants and thermal power plants amounted to 5,4 million PLN in 2011 (Ochrona środowiska 2013; Obwieszczenie Ministra Środowiska 2010).

Table 3. Emissions of gases and estimates of emission charges paid by power plants and by other sectors in Poland in 2011

\begin{tabular}{|l|c|c|c|c|c|}
\hline \multicolumn{1}{|c|}{ Specification } & \multicolumn{1}{|c|}{$\begin{array}{c}\text { Carbon } \\
\text { dioxide }\end{array}$} & $\begin{array}{c}\text { Carbon } \\
\text { oxide }\end{array}$ & $\begin{array}{c}\text { Nitrogen } \\
\text { oxides }\end{array}$ & $\begin{array}{c}\text { Sulphur } \\
\text { dioxide }\end{array}$ \\
\hline \hline \multicolumn{3}{|c|}{ Emission (thousand tonnes) } & 228,24 & 357,46 \\
\hline Power plants and thermal power plants & $148.573,00$ a) & 41,85 & 47,42 & 122,21 \\
\hline $\begin{array}{l}\text { Other combustion in energy production and } \\
\text { transformation industries (e.g. refineries) }\end{array}$ & $\cdot$ & 20,55 & & 180,24 \\
\hline Combustion in industry &. & 253,84 & 74,76 & 1 \\
\hline
\end{tabular}

${ }^{2}$ Estimations of charges paid by power plants are likely more reliable than estimations of charges paid by other sectors. This is due to the fact that many smaller entrepreneurs avoid paying charges. In addition, low emissions are exempt from the charges. 


\begin{tabular}{|l|c|c|c|c|}
\hline \multicolumn{1}{|c|}{ Specification } & $\begin{array}{c}\text { Carbon } \\
\text { dioxide }\end{array}$ & $\begin{array}{c}\text { Carbon } \\
\text { oxide }\end{array}$ & $\begin{array}{c}\text { Nitrogen } \\
\text { oxides }\end{array}$ & $\begin{array}{c}\text { Sulphur } \\
\text { dioxide }\end{array}$ \\
\hline \hline Commercial and institutional plants & - & 17,30 & 18,91 & 25,42 \\
\hline Householdsc) & - & 1484,83 & 60,61 & 185,24 \\
\hline Total emissions (thous. tonnes) & $306.138,93$ b) & $2.915,78$ & 850,75 & 910,05 \\
\hline
\end{tabular}

Estimates of charges paid by the sector (million PLN)c)

\begin{tabular}{|l|c|c|c|c|}
\hline Power plants and thermal power plants & 39 & 5 & 110 & 172 \\
\hline $\begin{array}{l}\text { Other combustion in energy production } \\
\text { and transformation industries (e.g. refineries) }\end{array}$ & $\cdot$ & 2 & 23 & 59 \\
\hline Combustion in industry & $\cdot$ & 28 & 36 & 87 \\
\hline Commercial and institutional plants &. & 2 & 9 & 12 \\
\hline \hline
\end{tabular}

a) 2010 .

b) Households are generally exempted from the charges.

c) In 2011 the rates of charge were 0,26 PLN per ton of $\mathrm{CO}_{2}, 0,11$ PLN per kg of $\mathrm{CO}$ and 0,48 per tonne of $\mathrm{SO}_{2}$ and $\mathrm{NOx}$.

S o u r c e : own elaboration based on: Ochrona środowiska 2013,229, 231; Strategia Bezpieczeństwo Energetyczne 2013, Obwieszczenie Ministra Środowiska 2010.

In Poland revenues from charges on the use of the environment are earmarked for financing environmental expenditure. Based on the above estimates one can assume that at least $17 \%$ of environmental charge revenue is generated by emission charges levied on energy sector ${ }^{3}$. Some of the those revenues are distributed back to polluters in the form of subsidies for "green" investments such as flue gas desulphurization projects.

Undoubtedly, the fiscal impact of the charges is important. However, the charges should most of all encourage polluters to reduce emissions. The en-

3 In 2011 total revenues from charges on the use of environment in Poland were 1,9 billion PLN. The estimates of revenues from emission charges paid by power plants are underestimated. The analysis ignores the revenues from emission charges paid levied on other substances than $\mathrm{CO}_{2}, \mathrm{CO}, \mathrm{SO}_{2}, \mathrm{NO}_{\mathrm{x}}$ and heavy metals. In addition, the analysis could also include other environmental charges paid by power plants that is charges on water abstraction, water pollution and waste disposed in landfills. Such analysis would be difficult due to lack of data and complex design of the latter charges. However one can assume that charges on wastewater and charges on waste generated by power plants raise relatively low revenues (see table 3 ). 
vironmental impact of charges is difficult to estimate ${ }^{4}$. For example, some authors suggest that differences in the rates of emission charges levied in Poland on various substances do not reflect differences in the environmental impact of those substances. According to their propositions rate on $\mathrm{SO}_{2}$ should be twice as high as rate of charge on $\mathrm{NO}_{\mathrm{x}}$ (Hilse, Kapała, Olczak 2013). T. Żylicz (2012) suggests that the rate of charge on sulphur dioxide in Poland is many times lower than environmental damage from $\mathrm{SO}_{2}$ emissions. Therefore, it can be assumed that the slight increase in the rates of charges would only generate additional revenues for environmental funds. Perhaps, the emission reductions are achieved mainly by administrative instruments (emission limits) ${ }^{5}$.

In order to examine the burden of environmental charges imposed on energy company a case study approach has been adopted. It is based on data provided by power generation company TAURON Wytwarzanie SA which is a producer of electricity and a producer and a supplier of steam. The company has 4.671 MW of installed electrical capacity and $1.496 \mathrm{MW}$ of thermal power. It consists of seven power plants: Blachownia, Halemba, Jaworzno III, Łagisza, Łaziska, Siersza, Stalowa Wola (O spółce TAURON).

Information provided in the company's sustainability report suggests that in 2012 TAURON Wytwarzanie SA paid charges for the use of the environment of 41,1 million PLN into the accounts of relevant Marshal Offices. Table 4 shows that these charges consist primarily of charges for emissions of gas and particles into air. These charges accounted for approximately $5,4 \%$ of total air pollution charges paid in Poland.

A few power plants which belong to the company participate in the Eco-Management and Audit Scheme and produce and make publicly available periodic environmental statements providing the public and other interested parties with information on their environmental performance (Regulation No 1221/2009). One of these power plants is Jaworzno III (śląskie voivodeship) - a power plant with a total capacity of $1.535 \mathrm{MWe}$ and $371 \mathrm{MWt}$. Jaworzno III uses coal and biomass as fuel. It consists of two plants (Deklaracja środowiskowa 2012, 4): Elektrownia II - a combined heat and power plant producing electricity and heat in cogeneration and Elektrownia III - a public power plant. In

${ }^{4}$ It is worth noting that between 1995 and 2011 SO$_{2}$ emissions from power plants decreased by $70 \%$ and NOx emissions by $24 \%$. In the same period, the rates of emission charges increased nearly two and half times.

${ }^{5}$ Such a situation occurred in the Czech Republic where the rates of emission charges are to be significantly increased (Emisní poplatky 2012). 
2012 Elektrownia II emitted 1,78 thousand tons of $\mathrm{SO}_{2}$ and 0,85 thousand tons of $\mathrm{NO}_{\mathrm{x}}$. Emissions from Elektrownia III were much higher. The plant has emitted 5,88 thousand tons of $\mathrm{SO}_{2}$ and 9,23 thousand tons of $\mathrm{NO}_{\mathrm{x}}$ (Deklaracja środowiskowa za rok 2011 2012, 14; Deklaracja środowiskowa 2012, 16-17). Assuming that the data on air emissions from both power plants were used as the basis for the calculation of charges ${ }^{6}$ for use of the environment one can suppose that in 2012 Jaworzno III Power Plant paid charges of approximately 3,75 million PLN - for sulphur dioxide emissions and 4,94 million PLN - for nitrogen oxides emissions. It should be noted that the overall revenue from air pollution charges in Silesian Voivodeship in 2012 was 126,4 million PLN (Ochrona środowiska 2013, 469).

Table 4. Charges for the use of the environment paid in 2012 by TAURON Wytwarzanie SA

\begin{tabular}{|l|c|c|c|}
\hline \multirow{2}{*}{\multicolumn{1}{c}{ Charge }} & \multicolumn{2}{|c|}{ Paid charges } \\
\cline { 2 - 4 } & In thous. PLN & $\begin{array}{c}\text { In percent of total } \\
\text { environmental charges } \\
\text { paid by TAURON Wy- } \\
\text { twarzanie SA }\end{array}$ & $\begin{array}{c}\text { In percent of total envi- } \\
\text { ronmental charges paid } \\
\text { in Poland for the given } \\
\text { use of the environment }\end{array}$ \\
\hline \hline Air pollution charge & 39369,2 & 95,7 & $5,4^{\text {a) }}$ \\
\hline Water abstraction charge & 1697,8 & 4,1 & $0,4^{\text {b) }}$ \\
\hline Wastewater charge & 76,7 & 0,2 & $0,0^{\text {b) }}$ \\
\hline Charge on waste & 0,0 & 0,0 & $0,0^{\text {c) }}$ \\
\hline Total & 41143,7 & 100,0 & $2,3^{\text {d) }}$ \\
\hline \hline
\end{tabular}

a) In percent of total air pollution charges.

b) In percent of charges on water abstraction and pollution.

c) In percent of landfill charges.

d) In percent of total charges for the use of the environment.

S o u r c e : Raport Zrównoważonego Rozwoju, 64; Ochrona środowiska 2013, 469.

\section{THE CONCLUSIONS FROM THE RESEARCH}

The analysis showed that the Polish power sector emits relatively large amounts of pollutants into the atmosphere. Emission charges paid by power sta-

${ }^{6}$ According to the environmental statement of Jaworzno III data on emissions into air are in accordance with information for charges. 
tions represent a significant part of the total revenues from charges on the use of the environment and play an important role in the environmental protection financing system. It is very important to analyze whether the environmental charges in Poland stimulate pollution control or are only fiscal in character. The presented data suggest that rates of emission charges applied in Poland are many times lower than emission tax rates in the countries of Northern Europe. One can also specify some desired improvements in the design of emission charges (for example reduction of the number of substances subject to charges or the modification of differences between rates of charges on different substances).

In addition to the air pollution charges power stations pay landfill charges, water abstraction charges and charges on wastewater. The amount of paid charges is difficult to estimate due to the lack of available data and a fairly complex structure of these charges. A case study analysis has show that revenues from charges on wastewater and on waste going to landfill are significantly lower than revenues from emission charges.

\section{REFERENCES}

Database on instruments used for environmental policy, http://www2.oecd.org/ecoinst/queries/ (accessed: 17.03.2014).

Deklaracja środowiskowa wg Rozporządzenia EMAS (2011), PGE Górnictwo i Energetyka Konwencjonalna Spółka Akcyjna, Oddział Zespół Elektrowni Dolna Odra, Nowe Czarnowo, http://www.gdos.gov.pl/files/EMAS/2012/PGE_DOLNA_ODRA_2012. pdf (accessed: 08.03.2014).

Deklaracja środowiskowa za rok 2011 (2012), TAURON Wytwarzanie Spółka Akcyjna - Oddział Elektrownia Jaworzno III w Jaworznie, http://bip.gdos.gov.pl/doc/ ftp/2012/TAURON_Jaworzno\%20_2012.pdf (accessed: 08.03.2014).

Deklaracja środowiskowa za rok 2012 (2013), TAURON Wytwarzanie Spółka Akcyjna - Oddział Elektrownia Jaworzno III w Jaworznie, http://bip.gdos.gov.pl/doc/ ftp/2013/Deklaracja_Srodowiskowa_za_2012_Elektrownia_Jaworzno_III_pl_wydanie_IV.pdf (accessed: 08.03.2014).

Elektrimajanduse regulatiivne keskkond, Energiatalgud, http://www.energiatalgud.ee/ index.php?title=Elektrimajanduse_regulatiivne_keskkond (accessed: 10.08.2014).

Emisní poplatky 2012, Energostat (2012), http://www.energostat.cz/emisni-poplatky. html (accessed: 10.08.2014).

Excise duty on emissions of NOx. 2014, http://www.toll.no/upload/aarsrundskriv/2014/2014\%20Emissions\%20of\%20NOx.pdf (accessed: 10.08.2014).

Gad S., Pawlak A., Różowicz S. (2013). Analiza opłat korzystania ze środowiska z perspektywy energetyki zawodowej. Przegląd Elektrotechniczny, 8, 42. 
Hilse D., Kapała J., Olczak C. (2013). Ekonomiczny model i narzędzia zarządzania ochroną powietrza na przykładzie zakładu koksowniczego. Inżynieria Ekologiczna, 32.

Lorenz U. (2005). Węgiel jako paliwo z przyszłością. Przegląd Górniczy, 61.

O spółce TAURON Wytwarzanie SA, http://www.tauron-wytwarzanie.pl/o-spolce/ Strony/o-spolce.aspx (accessed: 17.03.2014).

Obwieszczenie Ministra Środowiska z dnia 13 sierpnia 2013 r. w sprawie wysokości stawek opłat za korzystanie ze środowiska na rok 2014 (M.P. z 2013 r., poz. 729).

Obwieszczenie Ministra Środowiska z dnia 4 października 2010 r. w sprawie wysokości stawek opłat za korzystanie ze środowiska na rok 2011 (M.P. $2010 \mathrm{nr} 74$ poz. 945).

Ochrona środowiska 2013, Główny Urząd Statystyczny (2013), Warszawa, 229, 231, 469, http://www.stat.gov.pl/gus/5840_1526_PLK_HTML.html (accessed: 10.02.2014).

Poskrobko B. (ed.) (1999), Opłaty za emisję zanieczyszczeń do powietrza, Wydawnictwo Ekonomia i Środowisko, Białystok.

Pyssa J. (2005). Odpady z energetyki - przemysłowe zagospodarowanie odpadów z kotłów fluidalnych. Gospodarka Surowcami Mineralnymi, 21, 3, 83-84.

Raport Zrównoważonego Rozwoju - 2012, TAURON Polska Energia, http://raportyspoleczne.pl/wp-content/uploads/raports/2137c370fd65b7b2bdb11c541ec269a7.pdf.

Regulation No 1221/2009 of the European Parliament and of the Council of 25 November 2009 on the voluntary participation by organisations in a Community eco-management and audit scheme (EMAS), repealing Regulation (EC) No 761/2001 and Commission Decisions 2001/681/EC and 2006/193/EC.

Skatter i Sverige - Skattestatistiskårsbok (2011), Skatteverket, 143, http://www.skatteverket.se/privat/sjalvservice/blanketterbroschyrer/broschyrer/info/152.4.39f16 f103821c58f680007237.html (accessed: 14.03.2014).

Strategia Bezpieczeństwo Energetyczne i Środowisko. Perspektywa do 2020 r. - projekt (2013), Ministerstwo Gospodarki, Ministerstwo Środowiska, Warszawa, http://bip. mg.gov.pl/node/19680.

Tax.dk, http://www.tax.dk/jv/ea/E_A_7_11_6.htm (accessed: 10.08.2014).

The Swedish tax on nitrogen oxide emissions lessons in environmental policy reform (2013), OECD Environment Policy Paper, http://www.oecd-ilibrary.org/docserver/ download/5k3tpspfqgzt.pdf?expires $=1398162101 \& \mathrm{id}=\mathrm{id} \&$ accname $=$ guest $\&$ check sum=4FDB92580FCE0C610D7B48CD8DC887D3 (accessed: 14.03.2014).

Żylicz T. (2012). Polskie opłaty ekologiczne. Aura, 04. 